$\begin{array}{ll}\text { Research Square } & \begin{array}{l}\text { Preprints are preliminary reports that have not undergone peer review. } \\ \text { They should not be considered conclusive, used to inform clinical practice, } \\ \text { or referenced by the media as validated information. }\end{array}\end{array}$

\title{
Husband's Knowledge and Involvement in the Reproductive Rights of Women in Harar, Eastern Ethiopia
}

\section{Aminu Mohammed \\ Dire Dawa University}

\section{Tadesse Alemayehu}

Haramaya University College of Health Sciences: Haramaya University College of Health and Medical Sciences

Assefa Desalew ( $\nabla$ assefad100@gmail.com)

Haramaya University College of Health Sciences: Haramaya University College of Health and Medical Sciences https://orcid.org/0000-0001-6065-0708

\section{Yalelet Belay}

Dire Dawa University

\section{Alekaw Sema}

Dire Dawa University

\section{Adera Debella}

Haramaya University College of Health Sciences: Haramaya University College of Health and Medical Sciences

\section{Yadeta Dessie}

Haramaya University College of Health Sciences: Haramaya University College of Health and Medical Sciences

\section{Research}

Keywords: Husband, Reproductive rights, Knowledge, Involvement, Women, Harar, Ethiopia

Posted Date: November 19th, 2020

DOI: https://doi.org/10.21203/rs.3.rs-110428/v1

License: (c) (i) This work is licensed under a Creative Commons Attribution 4.0 International License. Read Full License 


\section{Abstract}

Objective: Reproductive rights violations are a serious public health concern worldwide, particularly in Sub-Saharan Africa including Ethiopia, where more than $38.83 \%$ of victims are living. Understanding the status of husbands' knowledge and involvement helps to set important programs and interventions. However, there is a paucity of data related to husbands' roles in women's reproductive rights in the study setting. Therefore, this study aimed to assess husbands' knowledge and involvement in women's reproductive rights and associated factors in Harar, eastern Ethiopia.

Methods: A community-based cross-sectional study was conducted on 611 husbands in March 2020. A multi-stage sampling and a systematic random sampling technique were used to select districts and study participants. Data were collected using an interviewer-administered questionnaire. Data were entered using EpiData 3.1 and analyzed with SPSS Version 22. Multivariable logistic regression was used to examine associated factors. An adjusted odds ratio (AOR) with a $95 \%$ confidence interval $(\mathrm{Cl})$ was used, and a p-value $<0.05$ was considered statistically significant.

Results: The magnitude of husbands' knowledge and involvement were $48.3 \%$ and $40.1 \%$ respectively. Social media utilization (AOR=4.97; 95\% Cl: 2.79-8.85), Spousal discussion (AOR=2.33; 95\% Cl: 1.60-3.39), nearby facility types: hospital (AOR=3.21; 95\% Cl: 1.23-8.36) and health post (AOR=2.86; 95\% Cl: 1.20-6.94) were associated factors with knowledge of husbands. Likewise, experience of using reproductive health services (AOR=2.15; 95\% Cl: 1.52-3.03), spousal discussion (AOR=1.95; 95\% Cl: 1.35-2.82), social media use (AOR=1.74; 95\% Cl: 1.05-2.89) and age 40 to 49 years (AOR=1.99, 95\% Cl: 1.19-3.32) were associated with husbands involvement.

Conclusions: Less than half of the husbands were knowledgeable and involved in the protection of partners' reproductive rights. Promoting and creating effective media utilization is very important to create awareness of reproductive rights. Moreover, using reproductive health services and empowering women to have an open discussion is crucial to increase the knowledge and involvement of husbands.

\section{Introduction}

Reproductive rights are the rights of an individual to decide and choose about reproduction free of discrimination, coercion, and violence $[1,2,3]$. The mid-1990s marked an important milestone internationally regarding the roles and responsibilities of men in the reproductive right of women $[4,5]$. Before this time, relevant policies, programs, and strategies were exclusively focused on women and promoted their roles in improving reproductive rights. The Cairo International Conference on Population and Development (ICPD), was the first global initiative that urged for extending the focus beyond women and emphasized the shared responsibility of men [1]. Subsequently, more initiatives began to target men in programs related to reproductive health including World Health Organization (WHO) and other international organizations $[1,2,3]$.

Globally one-third of women experience intimate partner violence (IPV) [6]. These violations are a serious public health concern throughout the world, but it's notably present in low and middle-income countries (LMICs) particularly in SubSaharan Africa including Ethiopia, where $38.83 \%$ of the women abused by their intimate partner $[7,8,9,10,11,12,13]$. Women's reproductive right needs due attention because of its violence happens worldwide and it is a serious challenge for the health of women $[1,7,14]$.

However, the lack of partners' knowledge of reproductive rights is among the factors related to IPV [15, 16]. The violence is related to physical, sexual, psychological, emotional, and access to reproductive education, and family planning [14]. Decrease utilization of women's healthcare services, unintended pregnancies, pregnancy-related symptom distress (antenatal, intranatal and postnatal depression), inadequate prenatal care, induced abortion, and sexually transmitted 
infections were the most frequent adverse maternal health-related outcomes after IPV during pregnancy that results in a high burden of maternal morbidity and mortality $[14,17,18,19,20,21,22,23]$.

Available evidence indicated that maternal health outcomes in LIMCs are related to the inadequacy of husbands' knowledge and involvement related to reproductive rights, lack of reproductive education, and spousal discussions which are the main cause of violations in reproductive rights $[22,24,25,26,27,28,29]$. Likewise, major contributing factors related to male partners' involvement in partners' reproductive rights are accessibility and utilization experience of reproductive health services, lack of spousal discussions on reproductive health and transportation access, and time to reach a health institution $[30,31,32]$.

To achieve the Sustainable Development Goals (SDGs), the United Nations agenda related to gender equality, and empowering all women which is important to ensure universal access to sexual and reproductive rights for women seated for 2030 [1]. Likewise, the Ethiopian minister of health set seven strategic directions to prevent women's reproductive and human rights $[6,33]$. Appropriately and effectively promoting the involvement of men in the protection of women's reproductive rights requires an understanding of the current status of husbands' knowledge and involvement helps to set important programs and interventions on maternal healthcare needs in general and respecting women's reproductive rights in particular. There is a paucity of data related to husbands' knowledge and involvement and associated factors on women's' reproductive rights in eastern Ethiopia. Therefore, this study aimed to assess husbands' knowledge and involvement in women's reproductive rights and associated factors in Harar, eastern Ethiopia.

\section{Methods And Material}

\section{Study setting and design}

A community-based cross-sectional study was conducted in March 2020 in Harari Regional State, eastern Ethiopia which is located $526 \mathrm{~km}$ from Addis Ababa, the capital city of Ethiopia. The region had an estimated 226,000 population with 125,000 urban and the remaining were rural populations [34]. This region is structured with 9 woredas (districts), six urban and 3 rural, and comprises 19 city kebeles (smallest administration unit) and 17 rural kebeles. We included all married male partners who have lived in Harar city. However, male partners who were severely ill and not living in the city during the study period were excluded.

\section{Sample Size and sampling procedure}

The sample size was determined using a single population proportion formula considering the following assumptions; $5 \%$ level of significance $(a=0.05), 95 \% \mathrm{Cl}$, a design effect of 1.5 , and a proportion of $50 \%$ (to obtain maximum sample).

Therefore, the final sample size for this study was 633 and $10 \%$ a non-response rate. $\mathrm{n}=\frac{(Z a / 2) 2 x p(1-p)}{d 2}$. The multi-stage sampling technique was used to select 4 districts using simple random sampling. Then from the selected district, we had selected 2 kebeles from each district using a simple random sampling technique. After that, we had distributed the sample to selected 8 kebeles based on proportionately allocated sample size. Finally, we had employed required study subjects using a systematic random sampling technique. A sampling interval $(k)$ of 5 was used for each kebeles to select male partners, where the first eligible man was selected using the lottery method.

\section{Data Collection Methods}

Data were collected using a pretested structured questionnaire adapted from different studies [15, 35] and modified to make inline with the local context. The questionnaire was translated from English into local languages (Affan Oromo and Amharic). Then, it was translated back into English to maintain consistency. The questionnaire contained three parts; socio-demographic characteristics, husband's knowledge, and involvement related to reproductive rights and reproductive 
health-related questions. Through face-to-face interviews, eight diploma nurses and midwives were collected the data, and two supervisors checked and monitored the data collection process daily. Regarding knowledge of reproductive rights, husbands who scored above the mean score value in the 11 knowledge measuring questions (each correct answer has a score $=1$, wrongly answered and do not know response scores $=0$ ) were considered knowledgeable. Likewise; Husband involvement was defined as partners' current support or help to his partner in use or exercising of her reproductive rights. We used 7 questions to assess husbands' level of involvement in partners' reproductive rights (each correct answer a score $=1$, each wrongly answered and do not know response score $=0$ ). Overall current involvement in partners' reproductive rights was categorized as good (score $\geq$ mean) and poor (score < mean) [35].

\section{Data Quality Control}

Two days of training was given to all the data collectors and supervisors. A pretest was carried out on $5 \%$ (Hakim district not included in the final sample) of the total sample size before the actual data collection. Based on the findings of the pretest, modifications to the questionnaire were made. The data collection process was closely supervised, and the completeness of each questionnaire was checked by the investigators and the supervisors daily. During data cleaning, a logical checking technique was employed to identify errors Finally, double data entry was performed to check the consistency of the data.

\section{Data Processing and Analysis}

The data were coded and entered into Epi Data Version 3.1 and exported to the Statistical Package for Social Sciences (SPSS) Version 22 statistical software for analysis. Univariate analysis was used to describe the frequency distribution of each variable. The outcome variables were coded as " 1 " for knowledgeable and good involvement, whereas " 0 " for not knowledgeable, and poor involvement of husbands. The association between the outcome variables and independent variables was analyzed using a logistic regression model. Covariates with a P-value $\leq 0.25$ were retained and entered into the multivariable logistic regression analysis using a forward stepwise approach. Multi-collinearity was checked to see the linear correlation among the independent variables by using variance inflation factor $(>10)$ and standard error $(>2)$ and goodness-of-fit was checked by Hosmer-Lemeshow test (>0.05). Adjusted odds ratio (AOR) with $95 \%$ confidence intervals $(\mathrm{Cl})$ using a $\mathrm{p}$-value $<0.05$ was considered a statistically significant association with the outcome variable.

\section{Results}

\section{Sociodemographic Characteristics}

A total of 611 study participants were included, yields a response rate of $96.5 \%$. The age of respondents ranged from 20 to 79 (mean \pm SD $=44 \pm 13.79$ ) years. Two hundred fifty-two (41.2\%) participants were employed. One hundred eightythree $(30.0 \%)$ husbands had a secondary and above level of education. More than four-fifth (84.1\%) of the respondents used social media, of which nearly three-fourth (75.3\%) used more than one social media weekly. Despite, 513 (82.3\%) respondents have lived near to the health facilities which is less than 30 minutes, the majority (91\%) of them reported that no access to reproduction education (Table 1). 
Table 1

Distribution of the study participants by their socio-demographics and source of information, Harar Town, March 2020, eastern Ethiopia March 2020. ( $N=611)$

\begin{tabular}{|c|c|c|c|}
\hline Variables & Category & Frequency & Percent \\
\hline \multirow[t]{4}{*}{ Age (in complete years) } & $<30$ & 119 & 19.5 \\
\hline & $30-39$ & 135 & 22.1 \\
\hline & $40-49$ & 164 & 26.8 \\
\hline & 50 and above & 193 & 31.6 \\
\hline \multirow[t]{4}{*}{ Occupation } & Employed & 252 & 41.2 \\
\hline & Merchant & 221 & 36.2 \\
\hline & Farmer & 116 & 19.0 \\
\hline & Laborer(daily) & 22 & 3.6 \\
\hline \multirow[t]{3}{*}{ Level of education } & No formal education & 52 & 8.5 \\
\hline & Primary(1-8th grade) & 376 & 61.5 \\
\hline & Secondary and above & 183 & 30.0 \\
\hline \multirow[t]{4}{*}{ Type of social media use } & Radio only & 16 & 2.6 \\
\hline & Television only & 98 & 16.0 \\
\hline & Newspaper only & 37 & 6.1 \\
\hline & More than one media use & 363 & 59.4 \\
\hline \multirow[t]{2}{*}{ Marriage type } & Arranged marriage & 507 & 83.0 \\
\hline & Love marriage & 104 & 17.0 \\
\hline \multirow[t]{3}{*}{ Time to reach a health institution 30 minutes } & 15 minutes or less & 178 & 29.1 \\
\hline & $16-30$ minutes & 335 & 53.2 \\
\hline & Above 30 minutes & 108 & 17.7 \\
\hline \multirow[t]{2}{*}{ Access to reproduction education } & Yes & 55 & 9.0 \\
\hline & No & 556 & 91.0 \\
\hline
\end{tabular}

\section{Knowledge of husbands about Partners' Reproductive Rights}

The mean Knowledge score was $5.64(S D \pm 1.65)$ with a minimum and a maximum score of 2 and 10 respectively. Accordingly, $48.3 \%$ (95\% Cl: 44.5-52.2) of the husbands were knowledgeable about the reproductive rights of their wives (Fig. 1). Participants were asked whether married women and men have equal reproductive rights and two hundred sixtyone $(42.7 \%)$ of them responded correctly. More than two-thirds $(68.2 \%)$ of husbands agreed that all married women must be free to enjoy and control their sexual and reproductive life as shown in (Table 2).

Table 2: Knowledge assessment related to husbands about Partners' Reproductive Rights in Harar town, eastern Ethiopia, March 2020. ( $\mathrm{N}=611)$ 


\begin{tabular}{|c|c|c|c|c|}
\hline Knowledge Questions & $\begin{array}{l}\text { Freq. } \\
\text { Yes }\end{array}$ & $\begin{array}{l}\text { Percent } \\
\%\end{array}$ & FrEq. No & $\begin{array}{l}\text { Percent } \\
\%\end{array}$ \\
\hline Married women and married men have equal reproductive rights & 261 & 42.7 & 350 & 57.3 \\
\hline $\begin{array}{l}\text { Married women have the right to acquire reproductive health-related } \\
\text { information/education where it is accessible without their partners' consent }\end{array}$ & 290 & 47.5 & 321 & 52.5 \\
\hline $\begin{array}{l}\text { Married women have the right that their reproductive health issues are kept } \\
\text { confidential/ secret }\end{array}$ & 365 & 59.7 & 246 & 40.3 \\
\hline $\begin{array}{l}\text { Married women have the right to maternity leave with adequate social } \\
\text { security benefits }\end{array}$ & 290 & 47.5 & 321 & 52.5 \\
\hline $\begin{array}{l}\text { Married women have no full right to access all Reproductive health services } \\
\text { without partners' consent }\end{array}$ & 352 & 57.6 & 259 & 42.4 \\
\hline $\begin{array}{l}\text { Married women have no right to autonomous reproductive service choices } \\
\text { without their partners' consent }\end{array}$ & 330 & 54.0 & 281 & 46.0 \\
\hline $\begin{array}{l}\text { Married women have no right to limit the number of their children according } \\
\text { to their desire without their partners' consent }\end{array}$ & 365 & 59.7 & 245 & 40.1 \\
\hline $\begin{array}{l}\text { All married women must be free to enjoy and control their sexual and } \\
\text { reproductive life }\end{array}$ & 417 & 68.2 & 194 & 31.8 \\
\hline $\begin{array}{l}\text { Married women have no right to use contraceptives without their partners' } \\
\text { consent }\end{array}$ & 276 & 45.2 & 335 & 54.8 \\
\hline It is sometimes justifiable/good for a husband to hit his partner & 241 & 39.4 & 370 & 60.6 \\
\hline A husband should get sex whenever he wants irrespective of partner's will & 247 & 40.4 & 364 & 59.6 \\
\hline
\end{tabular}

\section{Husband Involvement in Partners' Reproductive Rights}

The magnitude of the husbands' who had good involvement in partners' reproductive rights was $40.1 \%$ (95\% Cl: $36.2-$ 44). The mean score of involvement was $3.53(\mathrm{SD} \pm 1.65)$ and their minimum and maximum scores were 1 and 7 respectively. The majority (70.0\%) of study participants did not support the use of contraceptive methods for their partners, and 328 (53.7\%) husbands did not support reproductive education access to their partners. However, 346 (56.6\%) participants support partners to use reproductive services like prenatal care, facility-based delivery, and postnatal care as indicated in (Table 3). 
Table 3

Response of husband involvement questions about partners' reproductive rights in Harar Town, eastern Ethiopia, March 2020. $(\mathrm{N}=611)$

\begin{tabular}{|c|c|c|c|c|}
\hline \multirow[t]{2}{*}{ Involvement questions } & Yes & $\%$ & No & $\%$ \\
\hline & \multicolumn{2}{|l|}{$\mathbf{N}$} & \multicolumn{2}{|l|}{$\mathbf{N}$} \\
\hline Supporting partner to use contraceptive methods & 183 & 30.0 & 428 & 70.0 \\
\hline $\begin{array}{l}\text { Supporting partner to acquire reproductive right related information/education where it } \\
\text { is available }\end{array}$ & 283 & 46.3 & 328 & 53.7 \\
\hline Supporting partner to get sexual freedom & 335 & 54.8 & 276 & 45.2 \\
\hline $\begin{array}{l}\text { care for a partner to use health care services (like antenatal care, institutional delivery, } \\
\text { postnatal care) when needed }\end{array}$ & 320 & 52.4 & 291 & 47.6 \\
\hline $\begin{array}{l}\text { Supporting partner to use reproductive health care services like prenatal care, safe } \\
\text { delivery, and postnatal care }\end{array}$ & 346 & 56.6 & 265 & 43.4 \\
\hline $\begin{array}{l}\text { Supporting partner to use reproductive services like family planning, safe abortion, etc. } \\
\text { by her own choice }\end{array}$ & 349 & 57.1 & 262 & 42.9 \\
\hline Helping partner to know to have equal reproductive rights & 342 & 56.0 & 269 & 44.0 \\
\hline
\end{tabular}

Regarding the main reason for non-involvement in reproductive rights were being busy with other life issues, religion, living in different places, lack of knowledge, and money presented in Fig. 2.

\section{Factors Associated with husband Knowledge in Partners' Reproductive Rights}

In the multivariable logistic regression analysis, the use of social media, discussion on reproductive health, and type of nearby health facility were found to have a significant association with husbands' knowledge on the reproductive rights of their partners. Male partners who used social media were nearly 5 times (AOR $=4.97,95 \% \mathrm{Cl}: 2.79-8.85$ ) more likely to be knowledgeable than their counterparts. Partners who had an open discussion on their reproductive health were 2 times $(A O R=2.33,95 \% \mathrm{Cl}: 1.60-3.39)$ more likely to be knowledgeable on partners' reproductive rights than those partners who did not have a discussion. Moreover, male partners who had nearby a hospital (AOR $=3.21,95 \% \mathrm{Cl}$ : 1.23-8.36), and health post $(\mathrm{AOR}=2.86,95 \% \mathrm{Cl}: 1.20-6.94)$ were approximately 3 times more likely to be knowledgeable on partners' reproductive rights compared with their counterparts as shown in (Table 4). 
Table 4

Factors associated with knowledge of husbands about partners' reproductive rights in Harar Town, eastern Ethiopia, March 2020. $(\mathrm{N}=611)$

\begin{tabular}{|c|c|c|c|c|c|}
\hline \multirow[t]{2}{*}{ Variables } & \multirow[t]{2}{*}{ Category } & \multicolumn{2}{|l|}{ Knowledge } & \multirow[t]{2}{*}{$\operatorname{COR}(95 \% \mathrm{Cl})$} & \multirow[t]{2}{*}{$\operatorname{AOR}(95 \% \mathrm{Cl})$} \\
\hline & & Knowledgeable & $\begin{array}{l}\text { Not } \\
\text { Knowledge }\end{array}$ & & \\
\hline \multirow[t]{2}{*}{ Social media use } & Yes & $278(54.1 \%)$ & $\begin{array}{l}236 \\
(45.9 \%)\end{array}$ & $\begin{array}{l}5.54(3.20- \\
9.62) \star \star\end{array}$ & $\begin{array}{l}4.97(2.79- \\
8.85) \star \star\end{array}$ \\
\hline & No & $17(17.5 \%)$ & $80(82.5 \%)$ & 1 & 1 \\
\hline \multirow[t]{2}{*}{$\begin{array}{l}\text { Discussion on reproductive } \\
\text { health }\end{array}$} & Yes & $248(60.0 \%)$ & $\begin{array}{l}165 \\
(40.0 \%)\end{array}$ & $\begin{array}{l}2.87(2.02- \\
4.10) * \star\end{array}$ & $\begin{array}{l}2.33(1.60- \\
3.39) \star \star\end{array}$ \\
\hline & No & $68(34.3 \%)$ & $\begin{array}{l}130 \\
(65.7 \%)\end{array}$ & 1 & 1 \\
\hline \multirow[t]{4}{*}{$\begin{array}{l}\text { Type of nearby health } \\
\text { facility }\end{array}$} & Hospital & $52(53.1 \%)$ & $46(46.9 \%)$ & $\begin{array}{l}3.11(1.30- \\
7.65) \star \star\end{array}$ & $\begin{array}{l}3.21(1.23- \\
8.36) *\end{array}$ \\
\hline & Health center & $68(41.0 \%)$ & $98(59.0 \%)$ & $\begin{array}{l}1.91(0.80- \\
4.54)\end{array}$ & $\begin{array}{l}1.72(0.70- \\
4.30)\end{array}$ \\
\hline & Health post & 167 (52.7\%) & $\begin{array}{l}150 \\
(47.3 \%)\end{array}$ & $\begin{array}{l}3.10(1.32- \\
7.10) \star \star\end{array}$ & $\begin{array}{l}2.86(1.20- \\
6.94) *\end{array}$ \\
\hline & Clinics & $8(26.7 \%)$ & $22(73.3 \%)$ & 1 & 1 \\
\hline \multirow[t]{2}{*}{$\begin{array}{l}\text { Use of reproductive } \\
\text { services }\end{array}$} & Yes & 205 (56\%) & $161(44 \%)$ & $\begin{array}{l}1.54(1.11- \\
2.13) \star\end{array}$ & $\begin{array}{l}1.40(0.97- \\
1.98)\end{array}$ \\
\hline & No & $111(45.3 \%)$ & $\begin{array}{l}134 \\
(54.7 \%)\end{array}$ & 1 & 1 \\
\hline \multirow{3}{*}{$\begin{array}{l}\text { Husband education } \\
\text { Status }\end{array}$} & $\begin{array}{l}\text { Secondary and } \\
\text { above }\end{array}$ & 109 (59.6\%) & $74(40.4 \%)$ & $\begin{array}{l}2.01(1.10- \\
3.75)^{*}\end{array}$ & $\begin{array}{l}0.80(0.41- \\
1.50)\end{array}$ \\
\hline & Primary & $164(43.6 \%)$ & $\begin{array}{l}212 \\
(56.4 \%)\end{array}$ & $\begin{array}{l}1.05(0.60- \\
1.90)\end{array}$ & $\begin{array}{l}1.20(0.60- \\
2.38)\end{array}$ \\
\hline & $\begin{array}{l}\text { No formal } \\
\text { education }\end{array}$ & $22(42.3 \%)$ & $30(57.7 \%)$ & & 1 \\
\hline
\end{tabular}

Significant at: ${ }^{*} p=<0.05,{ }^{*} \mathrm{p}=<0.001$, COR; Crude Odds Ratio, AOR; AOR: Adjusted Odds Ratio

\section{Factors Associated with Husband Involvement in Partners' Reproductive Rights}

In the multivariable logistic regression analysis, discussion on reproductive health, experience in utilization of reproductive services, age of the husband (40-49) years, and social media use were significantly associated with male partners' involvement in the reproductive rights of women. Male partners who had experiences of using reproductive services were 2 times ( $A O R=2.15,95 \% \mathrm{Cl}$ : 1.52-3.03) more likely to be involved in partners' reproductive rights compared to those partners who did not have such experiences. Furthermore, Male partners who discussed reproductive health with his wife were similarly 2 times ( $\mathrm{AOR}=1.95,95 \% \mathrm{Cl}$ : $1.35-2.82$ ) more likely to be involved in partners' reproductive rights compared to those partners who did not have such discussion. Moreover, husbands who have used social media were 1.74 times $(A O R=1.74,95 \% \mathrm{Cl}$ : $1.05-2.89)$ more likely to be involved in partners' reproductive rights than those partners who did not use social media. Male partners who were in the age group between 40 and 49 years were 2 times $(A O R=$ 
1.99, 95\% Cl: 1.19-3.32) more likely to be involved in partners' reproductive rights compared to their counterparts (Table 5).

Table 5

Factors associated with the involvement of husbands on partners' reproductive rights in Harar Town, eastern Ethiopia, March 2020. $(\mathrm{N}=611)$

\begin{tabular}{|c|c|c|c|c|c|}
\hline \multirow[t]{2}{*}{ Variables } & \multirow[t]{2}{*}{ Category } & \multicolumn{2}{|l|}{ Involvement } & \multirow[t]{2}{*}{ COR $(95 \% \mathrm{Cl})$} & \multirow[t]{2}{*}{ AOR $(95 \% \mathrm{Cl})$} \\
\hline & & Good & Poor & & \\
\hline \multirow[t]{2}{*}{$\begin{array}{l}\text { Discussion on reproductive } \\
\text { health }\end{array}$} & Yes & $\begin{array}{l}273 \\
(66.1 \%)\end{array}$ & $\begin{array}{l}140 \\
(33.9 \%)\end{array}$ & $\begin{array}{l}2.20(1.56- \\
3.11) * \star\end{array}$ & $\begin{array}{l}1.95(1.35- \\
2.82)^{\star *}\end{array}$ \\
\hline & No & $93(47.0 \%)$ & $\begin{array}{l}105 \\
(53.0 \%)\end{array}$ & 1 & 1 \\
\hline \multirow[t]{2}{*}{$\begin{array}{l}\text { Reproductive service use } \\
\text { experience }\end{array}$} & Yes & $\begin{array}{l}249 \\
(68.0 \%)\end{array}$ & $\begin{array}{l}117 \\
(32.0 \%)\end{array}$ & $\begin{array}{l}2.33(1.67- \\
3.25)^{\star \star}\end{array}$ & $\begin{array}{l}2.15(1.52- \\
3.03)^{\star \star}\end{array}$ \\
\hline & No & $\begin{array}{l}117 \\
(47.8 \%)\end{array}$ & $\begin{array}{l}128 \\
(52.2 \%)\end{array}$ & 1 & 1 \\
\hline \multirow[t]{2}{*}{ Social media use } & Yes & $\begin{array}{l}295 \\
(57.4 \%)\end{array}$ & $\begin{array}{l}219 \\
(42.6 \%)\end{array}$ & $\begin{array}{l}0.49(0.30- \\
0.80) *\end{array}$ & $\begin{array}{l}1.74(1.05- \\
2.89)^{*}\end{array}$ \\
\hline & No & $71(73.2 \%)$ & $\begin{array}{l}26 \\
(26.8 \%)\end{array}$ & 1 & 1 \\
\hline \multirow[t]{3}{*}{$\begin{array}{l}\text { Time to reach a health } \\
\text { institution }\end{array}$} & $<15$ minutes & $94(52.8 \%)$ & $\begin{array}{l}84 \\
(47.2 \%)\end{array}$ & $\begin{array}{l}1.71(1.05- \\
2.81)^{\star}\end{array}$ & $\begin{array}{l}1.54(0.91- \\
2.58)\end{array}$ \\
\hline & $16-30$ minutes & $201(61.8 \%)$ & $\begin{array}{l}124 \\
(38.2 \%)\end{array}$ & $\begin{array}{l}1.20(0.75- \\
1.90)\end{array}$ & $\begin{array}{l}1.13(0.70- \\
1.83)\end{array}$ \\
\hline & $>30$ minutes & $37(34.3 \%)$ & $\begin{array}{l}71 \\
(65.7 \%)\end{array}$ & 1 & 1 \\
\hline \multirow[t]{4}{*}{ Age of Husband } & $<30$ years & $59(49.6 \%)$ & $\begin{array}{l}60 \\
(50.4 \%)\end{array}$ & 1 & 1 \\
\hline & $30-39$ years & $62(45.9 \%)$ & $\begin{array}{l}73 \\
(54.1 \%)\end{array}$ & $\begin{array}{l}1.44(0.87- \\
2.41)\end{array}$ & $\begin{array}{l}1.33(0.78- \\
2.27)\end{array}$ \\
\hline & $40-49$ years & $87(53.0 \%)$ & $\begin{array}{l}77 \\
(47.0 \%)\end{array}$ & $\begin{array}{l}1.97(1.21- \\
3.22) *\end{array}$ & $\begin{array}{l}1.99(1.19- \\
3.32) \star\end{array}$ \\
\hline & $\begin{array}{l}50 \text { and above } \\
\text { years }\end{array}$ & $76(39.4 \%)$ & $\begin{array}{l}117 \\
(60.6 \%)\end{array}$ & $\begin{array}{l}1.03(0.63- \\
1.66)\end{array}$ & $\begin{array}{l}1.19(0.72- \\
1.98)\end{array}$ \\
\hline
\end{tabular}

Significant at: ${ }^{\star} p=<0.05,{ }^{\star *} p=<0.001$, COR; Crude Odds Ratio, AOR; AOR: Adjusted Odds Ratio

\section{Discussion}

In United Nations 2030 Agenda for Sustainable Development, the international community has established the SDGs and set the target for countries to reduce maternal mortality ratio to less than 70 per 100,000 live births by 2030 [36]. Ethiopia has already declared its commitment to achieving the SDG targets. This implies that Ethiopia will need to significantly accelerate the progress rate. Expanding initiatives to include husbands and promoting their involvement in reproductive health could be considered as an important strategy for adaptation in this regard.

This study demonstrates that husbands' knowledge and involvement is a key factor in the protection of women's health. In this study, 48.3\% (95\% Cl: 44.5-52.2) of husbands are knowledgeable about the reproductive rights of their partners. 
This finding was in agreement with a study conducted in northern Ethiopia (Shire town, 47.1\%) [37]. This consistency might be related to the fact that there is a community health development army and HEWs are almost similar in the country in which they are doing health promotion, awareness creation, and the development of social media access. This finding was lower than studies conducted in Ghana (53.8\%) [16], Southern Ethiopia (Wolyta sodo, 54.5\%) [15], Northern Ethiopia (Gonder, 57.7\%) [38]. However, this finding was higher than studies conducted in India (9.1\%) [35] and northwest Ethiopia (Adet Tana Haik, 25.96\%) [39]. This disparity might be because of the differences in the socio-economic, cultural, religious, and level of education and awareness.

Regarding husbands' involvement, 40.1\% (95\% Cl: 36.2-44.0) participants had good involvement in partners' reproductive rights. This finding was in line with studies conducted in Bangladesh (40\%) [22], southern Ethiopia (Bale zone, 41.4\%) [24], and Afar, Ethiopia ( 42.2\%) [29]. This consistency might be related to the fact that there is a rising development intervention in many of these countries like community health promotion, awareness creation, and the development of social media access. However, this finding was lower than studies conducted in Tanzania (50.6\%) (28) and Nepal (57.6\%) [40]. But higher than a study conducted in Ethiopia (Harar, 19.7\%) [21] This disparity might be differences in study times, and socio-demographic characteristics level of implementation in the above-mentioned countries.

In this study, the use of social media, discussions on reproductive health, and type of nearby health facility were factors associated with husbands' knowledge. Male partners who used social media were almost five and two times more likely to be knowledgeable and involved in partners' reproductive rights compared to those partners who did not use it. This finding was in line with a study conducted in Bangladesh $[22,41]$. The possible explanation might be that a continuous and multidimensional community awareness through media, particularly on human rights, empowering women, and individual rights that can change the perception and knowledge of individuals $[6,22]$.

Moreover, male partners who had a hospital and health post nearby were almost three times more likely to be knowledgeable on partners' reproductive rights. This might be health facility access can result in changing the perception, belief, health norms, and practice of individuals. [16, 38, 42]. Furthermore, male partners who had discussed reproductive health were two times more likely to be knowledgeable and involved in practicing partners' reproductive rights of women. This finding is in agreement with studies conducted in Bangladesh [22]), India [43], and Kenya [44]. This can be explained by the fact that knowledge gained through experience sharing during the discussion can increase the knowledge in reproductive rights $[14,38,44]$.

Male partners aged 40 to 49 years were almost two times more likely to be involved in partners' reproductive rights. This finding is in line with a study conducted in Ghana [11]. This might imply that in this study majority were of maturity age and their level of education was secondary and above might increase their involvement in partners' reproductive rights.

As per this study, male partners' educational levels, occupation, having access to reproductive education, and experience of using reproductive services was not statistically significantly associated with husbands' knowledge and involvement in partners' reproductive rights. This was contrary to studies conducted in India [35], Bale Zone, Ethiopia [24], Arbaminch, Ethiopia [45], and Bangladesh [22] and southern Ethiopia [15]. The reason for the difference might be a disparity in the study sample and community health Nurses in India and Health Extension Workers in Ethiopia play a pivotal role in this difficulty $[3,14,25]$.

The study has some limitations: First, the cross-sectional nature of the study temporal relationship may not be assured. Second, it used self-reporting (interview response), which might have a social desirability bias. Some questions also required participants to recall, which could have affected the results. But efforts were made to manage through training of data collectors, and supervisors on how to approach respondents, interviewing male partners privately, and close supervision. 


\section{Conclusion}

Less than half of the husbands were knowledgeable and involved in the protection of partners' reproductive rights. The use of social media, type of nearby health facility, and spousal discussion of reproductive health showed a significant association with husbands' knowledge on partners' reproductive rights. Having spousal discussion, the experience of reproductive service use, social media use, and age (40-49) showed a significant association with male partners' involvement in partners' reproductive rights. Promoting and creating effective media utilization is very important to create awareness of reproductive rights. Moreover, using reproductive health services, empowering them to have an open discussion is crucial to increase the knowledge and involvement of husbands.

\section{Abbreviations}

AOR

Adjusted Odds Ratio

$\mathrm{Cl}$

Confidence Interval

COR

Crude Odd Ratio

ICDP

International Conference on Population Development

IHRERC

Institutional Health Research and Ethics Review Committee

IPV

Intimate Partner Violence

LMICs

Low and Middle-Income Countries

SDGs

Sustainable Development Goals

SPSS

Statistical Package for Social Sciences

WHO

World Health Organization

\section{Declarations}

Ethics approval and consent to participate

\section{Ethics approval and consent to participate}

Ethical clearance was obtained from the Institutional Health Research Ethics Review Committee of the College of Health and Medical Sciences, Haramaya University (IHRERC). Following approval, a written official letter of cooperation to district administrators. The administrators were informed about the objective of the study including the risks, benefits, and confidentiality issues. Informed written consent was obtained from all participants. Furthermore, confidentiality was assured throughout the process.

\section{Consent to publish}

Not applicable 
Availability of data and materials

All the data of this study are available from the corresponding author upon reasonable request.

\section{Competing interests}

The authors declare that they have no competing interests.

\section{Funding}

This work was financially supported by Haramaya University, Ethiopia. The funder has no role in the study selection, data collection, analysis, conclusion, and recommendation.

\section{Author contributions}

$A D, Y S$, and NT conceived and designed the study. AD drafted the manuscript. BG, FA, TW, KA, and AA extensively reviewed the manuscript and incorporated intellectual input. All authors read, provided feedback, and approved the final version of the manuscript.

\section{Acknowledgments}

We would like to thank Haramaya and Dire Dawa Universities for financial and unreserved technical support. We would also like to extend our gratitude to the Reginal Health Bureau, district heads, and the study participants for collaborations. Last but not the least, we would like to thank friends for their wonderful feedback on the scientific content of the manuscript.

\section{References}

1. ICPD. ICPD Beyond 2014 High-Level Global Commitments Implementing the Population and Development Agenda. ICPD Beyond. 2014.

2. World Health Organization (WHO). Sexual and reproductive health beyond 2014: Equality, Quality of Care, and Accountability. 2015.

3. UNDP. Ethiopia National Human Development Report 2018. Ind with a Hum Face. 2018;45.

4. Greene ME, Biddlecom AE. Absent and problematic men: Demographic accounts of male reproductive roles. Vol. 26, Population and Development Review. 2000. p. 81-115.

5. Bankole A, Singh S. Couples' Fertility and Contraceptive Decision-Making in Developing Countries: Hearing the Man's Voice. Int Fam Plan Perspect. 1998;24(1):15-24.

6. World Health Organization. RESPECT - Seven strategies to prevent violence against women. 2019. p. 2019.

7. UNDP. Industrialization with a Human Face: National Human Development Report 2018. 2018;108. Available from: http://hdr.undp.org/sites/default/files/ethiopia_national_human_development_report_2018.pdf

8. Shamu S, Abrahams N, Temmerman M, Musekiwa A, Zarowsky C. A systematic review of African studies on intimate partner violence against pregnant women: Prevalence and risk factors. PLoS One. 2011;6(3):1-9.

9. Devries KM, Mak JYT, García-Moreno C, Petzold M, Child JC, Falder G, et al. The global prevalence of intimate partner violence against women. Vol. 340, Science. 2013. p. 1527-8.

10. Berhe AA, Aregay AD, Abreha AA, Aregay AB, Gebretsadik AW, Negash DZ, et al. Knowledge, Attitude, and Practices on Water, Sanitation, and Hygiene among Rural Residents in Tigray Region, Northern Ethiopia. J Environ Public Health. 2020;2020. 
11. Quarcoo AE, Tarkang EE. Socio-demographic and structural predictors of involvement of the male partner in maternal health care in Hohoe, Volta Region, Ghana. Afr J Reprod Health. 2019;23(2):56-64.

12. United Nations Population Fund [UNFPA]. Sexualandreproductive healthandrights: anessentialelementof universalhealthcoverage. Icda25. 2019;48.

13. WHO. A practical tool for strengthening gender-sensitive national HIV and Sexual and Reproductive Health (SRH) monitoring and evaluation systems. 2016. p. 50-2.

14. WHO. World health statistics 2019: monitoring health for the SDGs, sustainable development goals. [Internet]. Geneva: World Health Organization; 2019. License: CC BY-NC-SA 3.0 IGO.: World Health Organization; 2019. p. 7584. Available from: https://apps.who.int/iris/bitstream/handle/10665/324835/9789241565707-eng.pdf

15. Adinew YM, Worku AG, Mengesha ZB. Knowledge of reproductive and sexual rights among University students in Ethiopia: Institution-based cross-sectional. BMC Int Health Hum Rights. 2013;13(1).

16. Yendaw E, Martin-Yeboah E, Bagah D. Knowledge, and Perception of Adolescents on Sexual and Reproductive Health Rights in Ghana: A Case Study of Yamoransa in the Mfantseman Municipality. Br J Educ Soc Behav Sci. 2015;8(3):147-58.

17. Teresa Rodrigues, Lúcia Rocha HB. Physical abuse during pregnancy and preterm delivery. Am J Obstet Gynecol [Internet]. 2008;198(2):171.e1-171.e6. Available from:

http://www.springerlink.com/content/gxkv6265668t4t12/\%5Cnpapers2://publication/uuid/BFAFEEFA-9EED-4EAEAF7A-E6859A2BA8C3

18. Martin SL, Li Y, Casanueva C, Harris-Britt A, Kupper LL, Cloutier S. Intimate partner violence and women's depression before and during pregnancy. Vol. 12, Violence Against Women. 2006. p. 221-39.

19. Chiman Sinha K. Male involvement and utilization of maternal health services in India. Int J Sci Res Publ [Internet]. 2014;4(1):2250-3153. Available from: www.ijsrp.org

20. Birhanu Z, Tushune K, Jebena MG. Sexual and Reproductive Health Services Use, Perceptions, and Barriers among Young People in Southwest Oromia, Ethiopia. Ethiop J Health Sci. 2018;28(1):37-48.

21. Asefa, Fekede, Ayele Geleto YD. Male Partners Involvement in Maternal ANC Care: The View of Women Attending ANC in Hararipublic Health Institutions, Eastern Ethiopia. Sci J Public Heal. 2014;2(3):182.

22. Bishwajit G, Tang S, Yaya S, Ide S, Fu H, Wang M, et al. Factors associated with male involvement in reproductive care in Bangladesh. BMC Public Health [Internet]. 2017;17(1):1-8. Available from: http://dx.doi.org/10.1186/s12889016-3915-y

23. WHO. Annual technical report: department of reproductive health and research, including UNDP/UNFPA/WHO/World Bank special program of research, development, and research training in human reproduction (HRP). World Health Organization. https://apps.who.int/ir. 2012.

24. Fetene K, Chanyalew W, Abebaw N, Gemechu G. Prevalence of male attendance and associated factors at their partner's antenatal visits among antenatal care attendees in Bale Zone, southeast Ethiopia. Int J Nurs Midwifery. 2018;10(9):109-20.

25. Kumar Yadav R, Ram Gahatraj N, Kumar Yadav D, Marahatta SB. Knowledge and Practice on Reproductive Health Rights among Married Women in Nepal. J Heal Allied Sci. 2019;5(1):53-7.

26. CSA. Ethiopia Mini Demographic and Health Survey. 2019.

27. Yargawa J, Leonardi-Bee J. Male involvement and maternal health outcomes: Systematic review and meta-analysis. J Epidemiol Community Health. 2015;69(6):604-12.

28. Chibwae A, Kapesa A, Jahanpour O, Seni J, Namanya B, Kadelya E, et al. Attendance of male partners to different reproductive health services in Shinyanga district, northwestern Tanzania. Tanzan J Health Res. 2018;20(2):1-11. 
29. Chekole MK, Kahsay ZH, Medhanyie AA, Gebrselassie MA, Bezabh AM. Husbands' involvement in family planning use and its associated factors in pastoralist communities of Afar, Ethiopia. Reprod Health. 2019;16(1):1-7.

30. Aregay A. Factors Associated with Maternal Health Care Services in Enderta District, Tigray, Northern Ethiopia: A Cross-Sectional Study. Am J Nurs Sci. 2014;3(6):117.

31. Kamimura A. Global Healthcare Issues and Proposed Solutions. Divers Equal Heal Care. 2018;15(2):10-2.

32. Egbe TO, Ketchen SA, Egbe E-N, Ekane GEH, Belley-Priso E. Risk Factors and Barriers to Male Involvement in the Choice of Family Planning Methods in the Buea Health District, South West Region, Cameroon: A Cross-Sectional Study in a Semi-Urban Area. Women's Heal - Open J. 2016;1(3):82-90.

33. Barot S. Sexual and Reproductive Health and Rights Are Key to Global Development: The Case for Ramping Up Investment. Guttmacher Policy Rev [Internet]. 2015;18(1):1-7. Available from: https://www.guttmacher.org/gpr/2015/02/sexual-and-reproductive-health-and-rights-are-key-global-developmentcase-ramping

34. Central Statistical Agency. Population Projection of Ethiopia for All Regions At Wereda Level from 2014 - 2017. J Ethnobiol Ethnomed [Internet]. 2013;3(1):28. Available from: http://www.csa.gov.et/images/general/news/pop_pro_wer_2014-2017_final

35. Bhattarai M, Dhakal R. Knowledge Regarding Reproductive Rights among Undergraduate Students. Sch J Appl Med Sci [Internet]. 2015;3(7A):2461-5. Available from:

https://www.academia.edu/33844336/Knowledge_Regarding_Reproductive_Rights_among_Undergraduate_Students

36. United Nations. The Sustainable Development Goals Report 2016. 2016.

37. Gg G, Gg W. Knowledge on reproductive and sexual rights and associated factors among youths, Shire town, Tigray, Northern Ethiopia. Int J Res Pharm Sci. 2016;6(2):30-7.

38. Gebresilassie K, Boke M, Yenit M, Baraki A. Knowledge level and associated factors about sexual and reproductive health rights among University of Gondar students, Gondar Ethiopia. Int J Sex Reprod Heal Care. 2019;2(1):016-20.

39. Ayalew M, Nigatu D, Sitotaw G, Debie A. Knowledge and attitude towards sexual and reproductive health rights and associated factors among Adet Tana Haik College students, Northwest Ethiopia: A cross-sectional study. BMC Res Notes [Internet]. 2019;12(1):1-7. Available from: https://doi.org/10.1186/s13104-019-4116-4

40. Bhusal CK, Bhattarai S. Social Factors Associated with Involvement of Husband in Birth Preparedness Plan and Complication Readiness in Dang District, Nepal. J Community Med Health Educ. 2018;08(06).

41. Lowe SMP, Moore S. Social networks and female reproductive choices in the developing world: A systematized review. Vol. 11, Reproductive Health. 2014.

42. World Health Organization (WHO). World health statistics 2017: monitoring health for the SDGs, Sustainable Development Goals. 2017.

43. Jungari S, Paswan B. What he knows about her and how it affects her? Husband's knowledge of pregnancy complications and maternal health care utilization among the tribal population in Maharashtra, India. BMC Pregnancy Childbirth. 2019;19(1):1-12.

44. Mangeni JN, Mwangi A, Mbugua S, Mukthar VK. Male involvement in maternal healthcare is a determinant of the utilization of skilled birth attendants in Kenya. East Afr Med J. 2012;89(11):372-83.

45. Asmare Gite, Nebila Liulseged, Habtewold Seyife, Yirgalem Abrha, Yinager Workineh, Mulugeta Shegaze, Aman Yesuf TY and M, Yihun. Reproductive System \& Sexual Disorders: Current Research Pregnancy Anaemia Prevalence and Associated Factors among Women. Reprod Syst Sex Disord Curr Res. 2016;5(4):20-5.

\section{Figures}




\section{Husband Knowledge on Partners' Reproductive Rights}

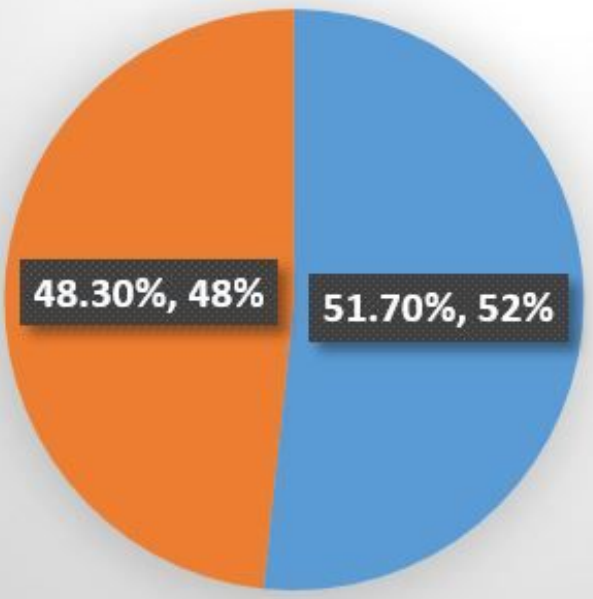

- Not Knowledgeable

Knowledgeable

\section{Figure 1}

Knowledge of husbands about Partners' Reproductive Rights Harar Town, eastern Ethiopia, March 2020. $(\mathrm{n}=611)$

\section{Husband Knowledge on Partners' Reproductive Rights}

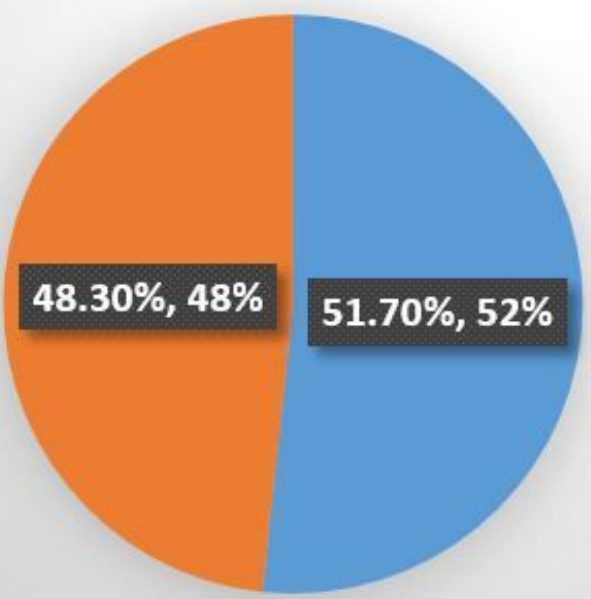

- Not Knowledgeable

Knowledgeable

\section{Figure 1}

Knowledge of husbands about Partners' Reproductive Rights Harar Town, eastern Ethiopia, March 2020. $(n=611)$ 


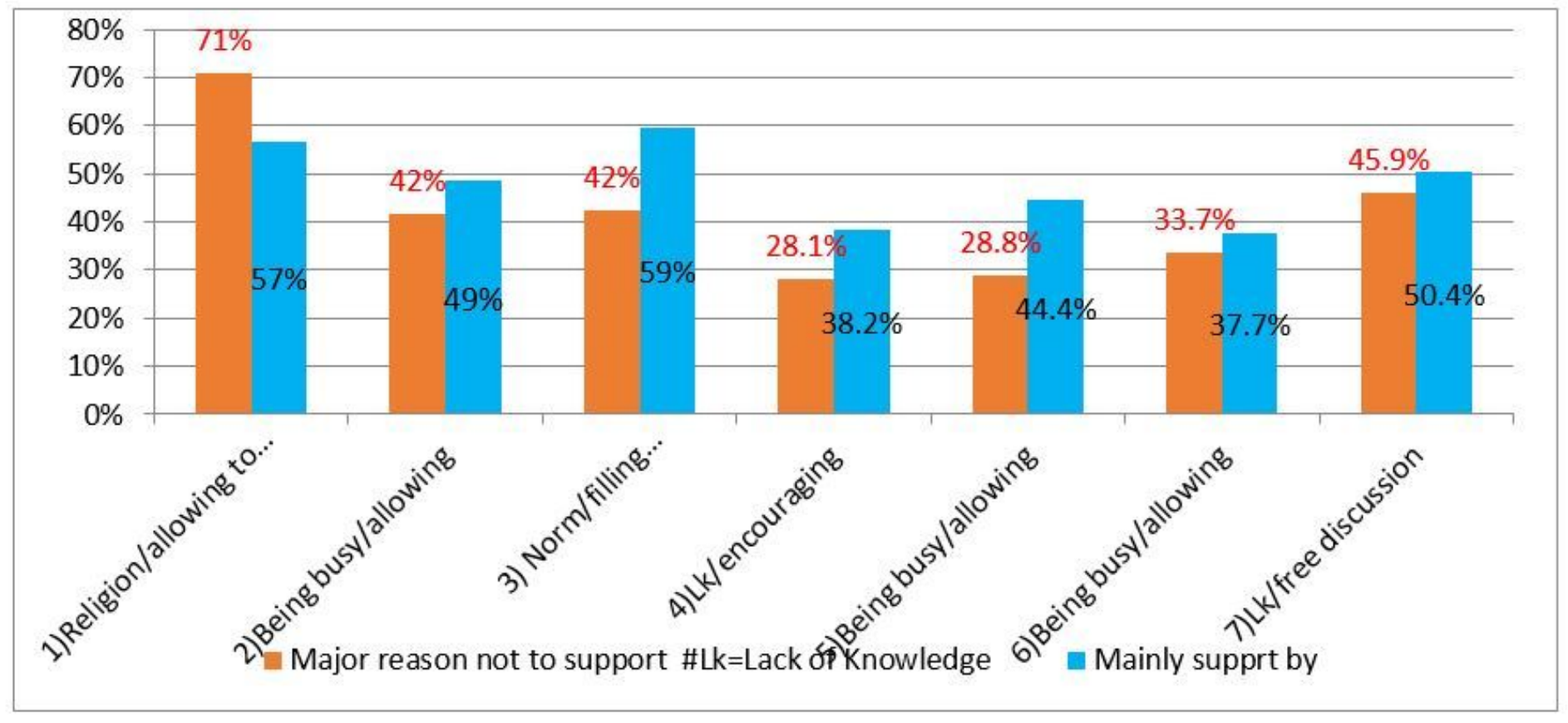

Figure 2

reasons for non-involvement of husbands in partners' reproductive rights for each question in Harar Town, eastern Ethiopia, March 2020. $(\mathrm{N}=611)$

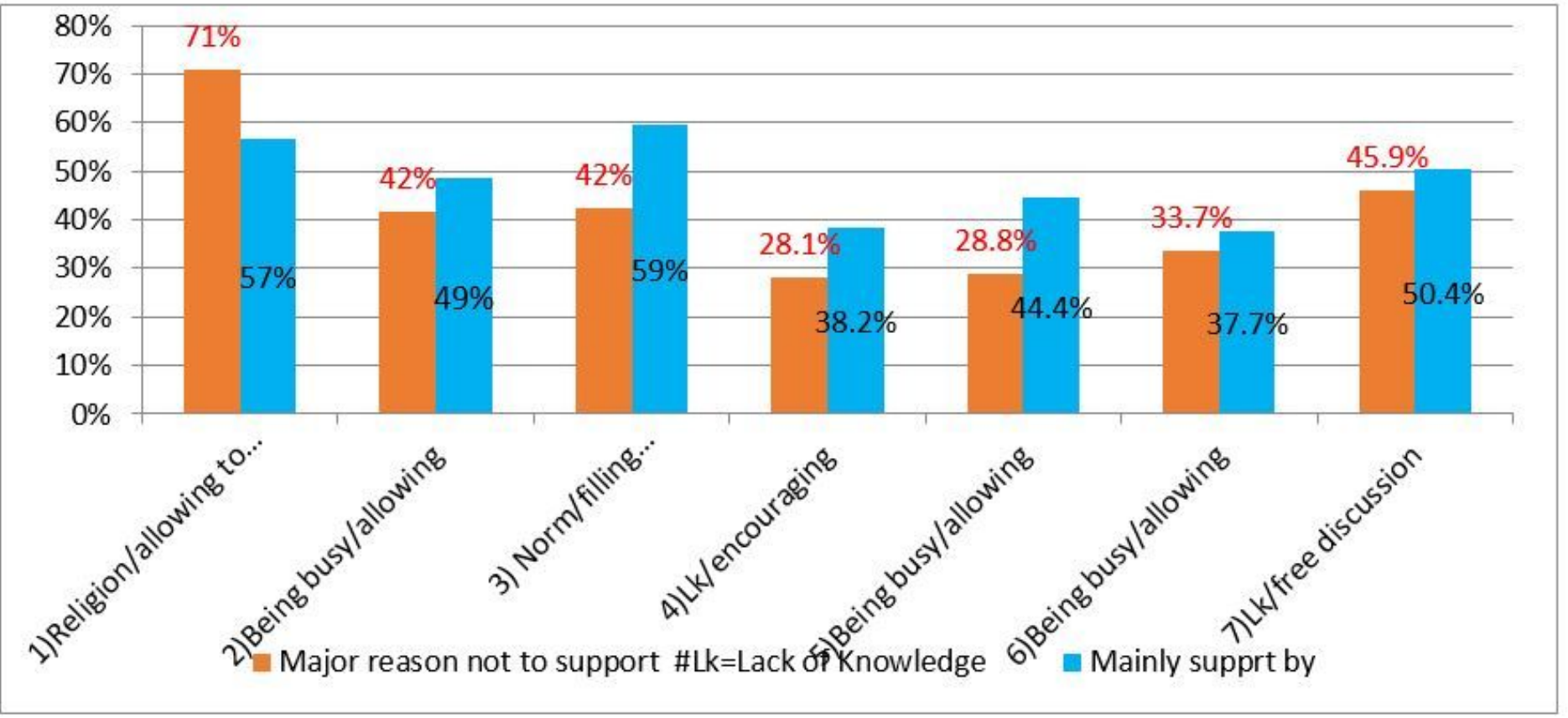

\section{Figure 2}

reasons for non-involvement of husbands in partners' reproductive rights for each question in Harar Town, eastern Ethiopia, March 2020. ( $\mathrm{N}=611)$ 